This item was submitted to Loughborough's Research Repository by the author.

Items in Figshare are protected by copyright, with all rights reserved, unless otherwise indicated.

\title{
Managing the health risks of extreme weather events by managing hospital infrastructure
}

PLEASE CITE THE PUBLISHED VERSION

https://doi.org/10.1108/ECAM-10-2012-0060

PUBLISHER

(C) Emerald

VERSION

SMUR (Submitted Manuscript Under Review)

\section{PUBLISHER STATEMENT}

This work is made available according to the conditions of the Creative Commons Attribution-NonCommercialNoDerivatives 4.0 International (CC BY-NC-ND 4.0) licence. Full details of this licence are available at: https://creativecommons.org/licenses/by-nc-nd/4.0/

\section{LICENCE}

CC BY-NC-ND 4.0

\section{REPOSITORY RECORD}

Loosemore, Martin, Vivien W. Chow, and Denny McGeorge. 2019. "Managing the Health Risks of Extreme Weather Events by Managing Hospital Infrastructure”. figshare. https://hdl.handle.net/2134/26735. 


\title{
Managing the health risks of extreme weather events by managing hospital infrastructure
}

\author{
Martin Loosemore ${ }^{1}$ Vivien W. Chow ${ }^{2}$ and Denny McGeorge ${ }^{3}$ \\ ${ }^{123}$ University of New South Wales, The Faculty of the Built Environment, Sydney, \\ NSW 2052, Australia
}

\begin{abstract}
Purpose - A predicted increase in climate change-related extreme weather events will present hospitals with new health-related and physical risks which were not originally anticipated in building and infrastructure designs. Markus et al.'s building systems model is used to analyse a range of adaptive strategies to cope with such events. The paper aims to discuss these issues.
\end{abstract}

Design/methodology/approach - Focus group interviews were conducted with a wide range of hospital stakeholders across three case study hospitals in Australia and New Zealand which have experienced extreme weather events.

Findings - It is concluded that effective adaptive strategies must balance responses across different organisational sub-systems. Contrary to previous research, the findings indicate that hospital managers do see hospital infrastructure as an important component of disaster response. However, it is the least adaptable of all response subsystems, making other options more attractive in the heat of a crisis.

Research limitations/implications - A focus on three case studies allowed the researchers to explore in-depth the experiences of stakeholders who had experienced extreme weather events. While producing highly valid results, the inherent limitation of this approach is the lack of breath. So further case studies are needed to generalise from the results.

Practical implications - Recommendations are made to improve the adaptive capacity of healthcare facilities to cope with the future health challenges of climate change risk.

Originality/value - By acknowledging that no one group holds all the knowledge to deal with extreme weather events, this paper capture the collective knowledge of all key stakeholders who have a stake in the process of responding effectively to such an event. It shows that hospital adaptation strategies cannot be considered in isolation from the surrounding emergency management systems in which a hospital is imbedded.

Keywords - Hospitals, Risk, Climate change, Systems, Adaptive capacity, Extreme weather

\section{Introduction}

Extreme weather events are caused when an individual climate variable such as wind speed temperature or rainfall "exceeds a particular threshold and deviates significantly from mean climate conditions" (Linnenluecke \& Griffiths, 2010, p. 2). In recent years there has been accumulating evidence of an increased incidence of such events (such as temperature extremes, floods and storms) and one of the most concerning impacts is anticipated to be on human health (Hennessy, et al., 2007; Stern, 2009). For example, in Australia, heatwaves kill more people than any other natural disaster and are associated with increased incidence of Malaria and Dengue 
fever, respiratory diseases and heatstroke and exhaustion (McMichael and Woodruff, 2007, Luber \& McGeehin 2008, PWC 2011). These health impacts affect the most vulnerable in our communities and are anticipated to increase into the future as populations age, grow and urbanise.

Given the implications of extreme weather events for human health, it is widely acknowledged that there is a need to better understand how to protect and improve the resilience of public health systems to such events (DEWR 2007, PCI 2011). However, previous research in facilities management has argued that buildings have long been an undervalued resource in many sectors including health and that the facilities management profession is itself at risk (Valins and Salter 1996, McGregor and Then 1999, Georgoulis 2008). Yet while new hospitals are relatively resilient to external forces, existing building stock is less resilient and there is a particular need to develop new adaptation strategies to address any new risks posed (DEWR, 2007). For example, recent extreme weather events have illustrated that many hospitals are built on floodplains, that floods can exert pressure on structures that can cause them to collapse and that water infiltration can damage equipment and services (often located in basements which are prone to flooding). Moving flood water is also a major problem during extreme weather and can undermine roads and foundations (FEMA 2010, 2012b, Helman et al. 2010). And the high winds which normally accompany storms can strip roof and wall coverings and even blow whole structures down. Equipment on the roof is especially vulnerable to wind and once loosened, flying debris may cause further danger to people and damage property (Mason \& Haynes 2010; Verdon-Kidd et al. 2010). In contrast, during heatwaves extreme temperatures can exceed the temperature tolerances of many existing construction materials, designs and heat management technologies causing them to break down and under-perform. Many patients' health depends on precisely controlled temperature and humidity conditions, meaning this can be a serious risk. And finally, hospital dependency on critical infrastructure such as electricity, gas and water has been found to be a major risk during extreme weather events since they are also likely to suffer serious outages (Hiete et al. 2011; AIHA 2010; Hampton 2011; WHO 2009b).

Within this context the aim of this paper is to discuss the types of adaptive strategies that can be put in place to deal with these new risks.

\section{Adaptive strategies to cope with extreme weather events}

Given growing international concern about the resilience of health facilities in the face of climate change, many countries have strengthened and developed legal frameworks, research and funding schemes for disaster reduction and climate change adaptation. For example, the Pan-American Health Organisation has published extensively on the structural integrity of hospitals, with special attention to high winds and earthquakes, including guides on how to construct, maintain and retrofit hospitals (PAHO 2008; WHO 2010). The United Nations International Strategy for Disaster Reduction (UNISDR) and the Hyogo Framework for Action are also addressing the broader task of global disaster reduction, which includes the safety and continual operability of health services (ISDR 2008; Shaw et al. 2010). Outside the UN, individual countries are also producing their own research and guidance. For example, in Australia, BRANZ produced a climate change adaptation report for the Australian Greenhouse Office (BRANZ 2007), which addressed climate 
change impacts on buildings and adaptation options. The National Climate Change Adaptation Research Facility (NCCARF) has produced several extreme weather case studies (Kiern et al. 2010), which take various approaches, and the Australian Building Codes Board has produced two recent drafts on flood mitigation (ABCB 2011). In the US, the Federal Emergency Management Agency's Building Science Branch develops and produces multi-hazard mitigation publications that aim to create disaster-resilient communities and reduce loss of life and property. These publications mainly focus on floods, high winds and earthquakes. FEMA's design guide for improving hospital safety provides important insights into multi-hazard mitigation for health facilities (FEMA 2007b) and is complemented by their design guide for improving critical facility safety (FEMA 2007a). In the UK the FloodProBE project aims to provide cost-effective solutions for flood risk reduction in urban areas. FloodProBE develop and test adaptation technologies and research ways of integrating flood protection into urban planning (van Ree et al. 2011). A review of the literature in this area (which includes the above) indicates the following strategies are widely recommended for different types of extreme weather events.

Flooding:

- Elevation - raise building above expected flood levels.

- Floodwalls and levees - to deny flood waters entry to an area.

- Dry flood proofing - to prevent water intrusion.

- Wet flood proofing - allows water to enter buildings in a controlled way.

Storms:

- Building design - Use smooth, regular and rounded shapes and materials. Avoid exterior-mounted equipment. Use a vestibule.

- Urban design - Adjacent buildings can produce a wind tunnel effect and tall trees may fall and damage buildings and harm people.

- Materials and specifications - Avoid unfixed materials, protect fragile materials like glass or use impact resistant materials particularly at lower levels. Use in-situ concrete structures and weather stripping.

Heatwaves: 
- Air-conditioning - Use HVAC systems keep internal environments at a constant temperature.

- Natural Ventilation - HVAC systems are vulnerable to electrical outages. Hence, incorporate advanced natural ventilation combined with good passive design with sensor controlled mechanical apertures and fans.

- Thermal insulation - Thermal insulation to keep indoor temperature constant with minimal heating and cooling.

- Shading - External shading can be provided by orientation, vegetation, other buildings and external panels. Also use shutters, curtains, blinds, window tinting and solar reflective coatings and chromogenic technology.

Having listed some of the common adaptive strategies recommended in the literature to manage the risks associated with extreme weather events, it is important to point out that multi-hazard mitigation is considered best practice. While it can be very costly to protect a building from one particular hazard, it is far more cost-effective to protect a building from multiple types of hazards (FEMA 2007b). Research has shown that different mitigation measures may reinforce or counter each other and FEMA provides a multi-hazard design matrix, which illustrates this. For example, shatter-proof thermochromic windows can withstand earthquakes and flying debris, and can also improve the thermal adaptive capacity of the building. Similarly, seals on doors can withstand both floodwaters and wind pressure. But the ultimate multihazard mitigation strategy is the concept of building autonomy which is a completely self-sustained hospital capable of providing all the services that are needed in the building, including electricity, heating, cooling, ventilation, water collection, conservation and treatment, sewage and waste treatment, recycling, and food production. However, while completely self-sustained buildings are possible, they are virtually non-existent, due to the high cost of implementing such designs. This is particularly the case for hospitals as they rely on more services than most building types (Achour \& Price 2010). It is therefore very difficult to make a hospital completely self-sustained. However, it is possible to ensure that a hospital can keep functioning at least for a few days by incorporating more built-in redundancies.

\section{Method}

To investigate the types of adaptive strategies which may be suitable in practice and their relative impacts on extreme weather event risks, our research employed a multiple case study approach. This is important in the context of this research because understanding the operation of hospitals requires more than a simple appreciation of building related issues. As Becker and Carthey (2007) point out, a hospital is a complex organisation with many diverse stakeholders and functions which need to interact in the delivery of appropriate health services to a community. Responses to extreme weather events are similarly complex and given their scale are likely to require many parts of these systems working together. They are also likely to involve an interplay of many economic, social, organisational, political and cultural forces which can only be explored fully using a case study approach. Other approaches to data collection, such as a large survey/questionnaire of people who have been involved in responding to such events would have failed to provide the 
depth of insight we needed to fully understand the social and organisational issues in this complex adaptive system.

The case studies are described below and were selected based on their size and age, population dependency, historical climatic records and future climatic predictions. Each of these facilities had also been subjected to a severe weather event, namely flash floods; floods caused by storm surges and; heatwaves respectively.

\section{Coffs Harbour Base Hospital}

Situated on the mid North Coast of NSW, Coffs Harbour Base Hospital serves a population of 100,000 . Coffs Harbour is a humid, sub-tropical area which means that flooding and storms are relatively common. While Coffs Harbour Base Hospital is relatively new, being operational only since 2001, the hospital suffers from its location adjacent to a creek and on a flood plain, and is one of the first areas in town to be inundated in a flooding event. Flood events have increased in frequency and intensity in recent years, with the region experiencing six major flooding events in 2009 alone.

\section{Whangarei Hospital}

Whangarei serves a district of 78,000 and is located in the North Island of New Zealand. The hospital is situated on a hill, and accessed by only one road which can be cut off during floods and storms. A major renovation was undertaken in 2001, but many of the buildings date from the 1950s-1960s. The NZ Ministry for the Environment warns that due to climate change, Northland's temperature is expected to raise by $3^{\circ} \mathrm{C}$ over the next century and the frequency of floods could increase fourfold by 2090 (Ministry for the Environment 2009).

\section{Ceduna District Health Services}

Ceduna is located in the remote northwest corner of the Eyre Peninsula, South Australia and is approximately 10 hours by road from Adelaide. Out of its small population of $3,731,25.5 \%$ of the population in 2006 identified themselves as indigenous i.e. of Aboriginal or Torres Strait Islander origin. Located within an arid zone, the town is exposed to hot, dry summers with limited rainfall, during which time the daytime temperatures can reach up to $47^{\circ} \mathrm{C}$ for a week or longer. In early 2009, when Adelaide reported up to 6 days over $40^{\circ} \mathrm{C}$, Ceduna recorded a temperature of $46.2^{\circ} \mathrm{C}$. Ceduna District Health Services offers a mix of 25 acute care beds and 10 beds for high level aged care, with a further 29 beds for low level aged care located on another site.

\section{Data collection}

Data collection was by means of a series of focus group sessions using a proprietary Risk and Opportunities Management System called ROMS (ROMS 2011). ROMS uses multimedia technology to provide a structured approach to help health sector stakeholders from varied backgrounds identify, assess and control the risks and opportunities associated with a nominated problem. In this case the problem posed was how to respond effectively to an extreme weather event scenario provided by our research team. Scenarios are a widely used method for helping stakeholders to think about risks and opportunities and in our cases the scenarios were generated 
from scientific advice and statistical evidence from the UNSW Climate Change Research Centre (a partner in this research). Given the different location of each case study hospital, three different scenarios were used which were relevant to each case study hospital's unique context. Namely, a flood scenario was posed for Coffs Harbour Hospital, a heatwave for Ceduna Hospital and a storm and flood for Whangarei Hospital.

By acknowledging that no one group holds all the knowledge to deal with extreme weather events, ROMS provides an interactive, inclusive and constructive process which is able to harness and capture the collective knowledge of all key stakeholders who have a stake in the process of responding effectively to such an event (Loosemore, 2010). ROMS uses focus groups as the mechanism to collect this information since they are widely recognised as an effective way to promote interaction and self-disclosure among a carefully structured group of respondents who can share their perspectives about a specific topic in a non-judgemental environment (Morgan 1997).

ROMS focus groups were run in two stages in each case study hospital with key stakeholders. Our focus group samples included: clinicians, emergency department staff, facility managers, nurses, technical staff, health care specialists and health service representatives. Stage one focus groups involved a one-day workshop to agree collective objectives in responding to an extreme weather event (ie. what resilience means for the stakeholders) and to identify and assess the risks and opportunities against these objectives. Stage two focus groups involved another oneday workshop with the same stakeholders to consider the controls which could reduce these risks to an acceptable level and maximise the opportunities which had been identified in the stage one focus groups.

\section{Discussion of results}

Although each case study faced a different scenario, we have sought here to present our results as one combined analysis in line with the efficient multi-hazard philosophy described above. To this end, the common organisational objectives across all case studies which emerged were, in order of priority:

1. Continuity of service delivery

2. Preserving the building structure's integrity along with its building services

3. Having effective communication both externally and internally

4. Maintaining access to and from the site

5. Ensuring availability and safety of relevant staff on hand to respond to the crises.

Across the three case studies a total of 90 risks were identified, assessed and ranked and 158 adaptive strategies were identified which if implemented, would reduce the risk profile to acceptable levels for our focus group stakeholders. These risks and controls were then represented as Rich Picture Diagram (RPD) to show the health sub system interdependencies which determine the health system's entire response to an extreme weather event (McGeorge et. al 2011) (see Figure 1). The advantage of RPD is that it overcomes the inherent limitations of traditional linear risk analysis methodologies which ignore subsystem interdependencies and wrongly assume that risks arise linearly and in isolation and that there is always some root 
cause to be searched for (Forrester 1994). In simple terms, a RPD is a pictorial multi-layered representation of the real world using symbols to represent subsystems and their relationships (of different types - communications, dependencies etc) within a defined system boundary (Patching 1990). The number of arrows surrounding a particular node (risk) on the RPD gives some measure of the overall level it poses to the system as a whole.

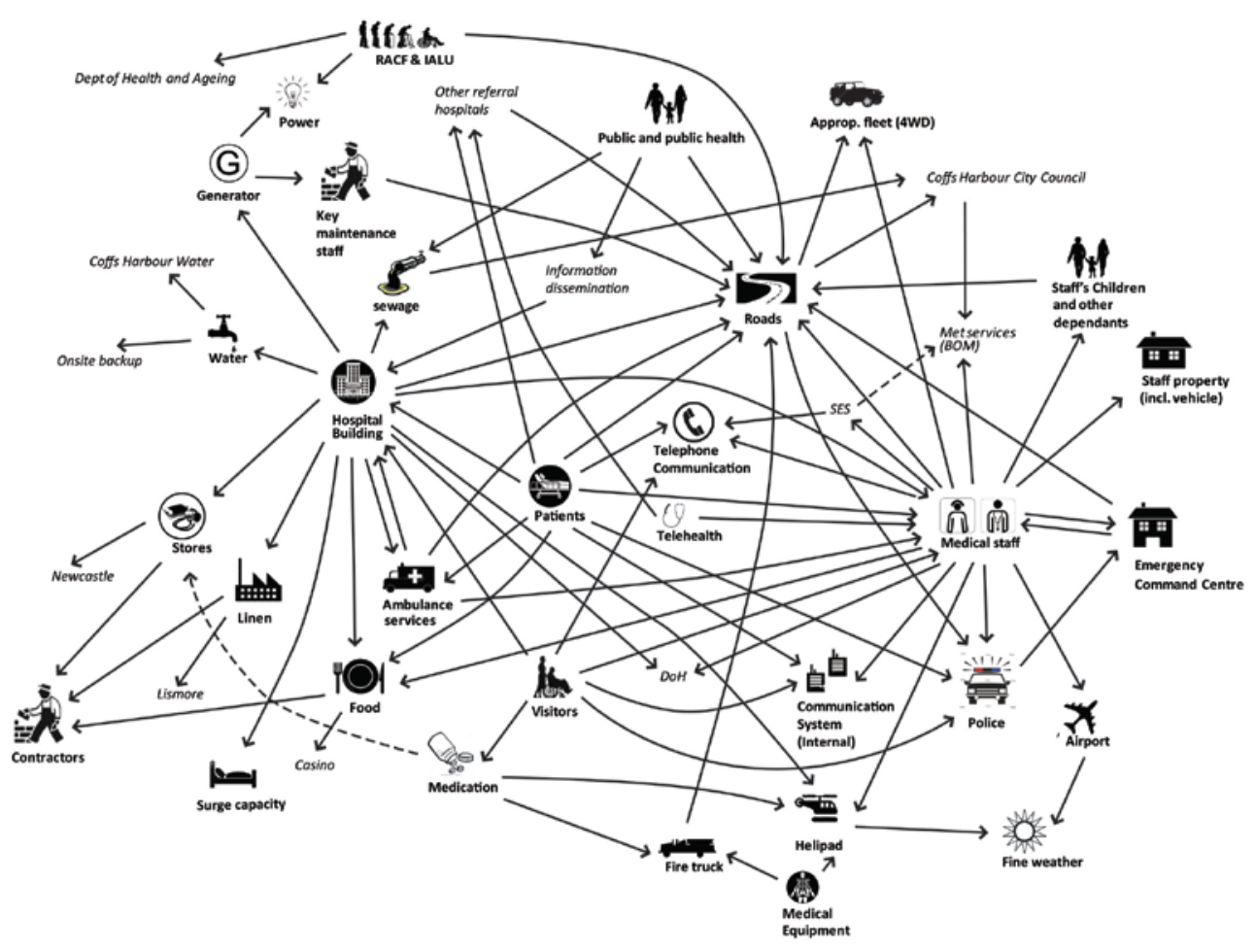

Figure 1 Rich Picture diagram of case study 1

In selecting additional controls to mitigate risk and maximise opportunity in a commercial setting, it is normal in risk management practice to select them on the basis of a cost/benefit comparison. The control which yields the greatest improvement (risk reduction) for the least cost will normally be chosen. However, in the context of health facilities, our stakeholders had a number of other considerations to make in addition to monetary costs. These included existing government policies (which are continually changing in the realm of healthcare), their own power within the organisation (health care is extremely hierarchical and political), and the unpredictability and severity of extreme weather events (we can only predict extreme weather events with a low level of granularity). These additional considerations added to the complexity of selecting appropriate controls. It also showed that their implementation would require the resilience of the whole system and thus necessitate hospital emergency managers to undertake a wide range of actions, from lobbying governments to moving equipment to different parts of the building to maximise its function or prevent damage etc. Furthermore, while our research was focussed on hospital infrastructure, it became evident that it is not 
possible to isolate this from the wider health system in which it is imbedded and that only some of the controls were building related. Potential controls often act together to have an effect which is greater than the sum of the parts, or conversely be cancelled out by a competing parameter or control in the wider health system. Finally, not all controls are completely within the influence of the health organisation in question (ie. lobbying the state government a good example).

In order to better understand the nature of possible controls a coding exercise was undertaken to categorise possible strategies to compare like-with-like and to identify any patterns that could be used towards formulating an adaptive strategy. Patterns were identified by examining co-occurrences such as correlation between "code items, themes, respondents or events" (Guest \& McLennan, 2003, p. 188). And each item coded was checked against the others to establish analytical categories, in a process referred to as 'constant comparison' (Pope et al 2000).

This analysis was, in essence, an exploration of "spheres of influence" (Pettigrew and McNulty 1995). To this end, the identified controls were separated into endogenous and exogenous categories and were then further broken down into 'within sphere of influence', 'partially within sphere of influence' and 'outside sphere of influence'. The term 'endogenous' refers to the sphere of influence of decision takers in the case study hospitals. The term 'exogenous' refers to the sphere of influence of external agencies, such as other government departments or private organisations. These categories reflect the nature of the healthcare systems which are characterised by a complex hierarchical structure of decision takers and governance regimes with varying spheres of influence.

It was clear from our second workshop that the likelihood of a control being proposed and, in turn, implemented is directly correlated to the degree of influence or authority which a stakeholder is able to exert over other actors in the health system. For example, in the case of Ceduna hospital, when faced with the challenge of needing to accommodate staff on site during a heatwave event, ideas of appealing to a higher authority for funding quickly turned inwards, with participants noting "I think we can do some of that ourselves... we could publically raise funds [from the local community] for couches and the like". Examples of endogenous and exogenous controls are provided in Table 1 although in practice the boundary between them is fuzzy.

Table 1 - Endogenous and exogenous controls

\begin{tabular}{|c|c|c|c|}
\hline & Categories & Definition & $\begin{array}{l}\text { Example (extracted } \\
\text { from ROMS workshop } \\
\text { transcripts) }\end{array}$ \\
\hline \multirow{3}{*}{ 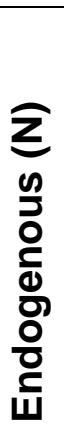 } & $\begin{array}{l}\text { Within sphere } \\
\text { of influence } \\
\text { (W) }\end{array}$ & $\begin{array}{l}\text { Actions that can easily be } \\
\text { implemented using existing } \\
\text { resources and associations within } \\
\text { the hospital organisation }\end{array}$ & $\begin{array}{l}\text { Set up a pseudo } \\
\text { pharmacy service for } \\
\text { visitors }\end{array}$ \\
\hline & $\begin{array}{l}\text { Partially within } \\
\text { sphere of } \\
\text { influence }(P)\end{array}$ & $\begin{array}{l}\text { Actions that will require } \\
\text { collaboration or assistance from } \\
\text { other health departments }\end{array}$ & $\begin{array}{l}\text { Develop support system } \\
\text { amongst local hospitals }\end{array}$ \\
\hline & $\begin{array}{l}\text { Outside } \\
\text { sphere of }\end{array}$ & $\begin{array}{l}\text { Strategic decisions relating to the } \\
\text { hospital that its organisation does }\end{array}$ & Build a new hospital \\
\hline
\end{tabular}




\begin{tabular}{|c|c|c|c|}
\hline & influence $(\mathrm{O})$ & not have the authority to make & \\
\hline \multirow{3}{*}{ 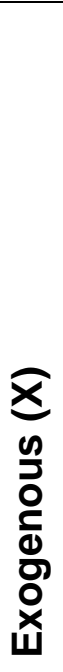 } & $\begin{array}{l}\text { Within sphere } \\
\text { of influence } \\
\text { (W) }\end{array}$ & $\begin{array}{l}\text { Actions involving or dealing with } \\
\text { outside bodies but which the } \\
\text { hospital organisation can easily } \\
\text { manage and control }\end{array}$ & $\begin{array}{l}\text { Educate public about } \\
\text { extreme weather event } \\
\text { risks }\end{array}$ \\
\hline & $\begin{array}{l}\text { Partially within } \\
\text { sphere of } \\
\text { influence }(P)\end{array}$ & $\begin{array}{l}\text { Actions involving or dealing with } \\
\text { outside bodies but which the } \\
\text { hospital organisation can manage } \\
\text { and control somewhat }\end{array}$ & $\begin{array}{l}\text { Negotiate with nearby } \\
\text { mining company to } \\
\text { share their helicopter } \\
\text { services for flying } \\
\text { patients in and out }\end{array}$ \\
\hline & $\begin{array}{l}\text { Outside } \\
\text { sphere of } \\
\text { influence }(O)\end{array}$ & $\begin{array}{l}\text { Actions involving or dealing with } \\
\text { outside bodies and which the } \\
\text { hospital organisation has little } \\
\text { scope or likelihood of management } \\
\text { and control }\end{array}$ & $\begin{array}{l}\text { Lobby commonwealth } \\
\text { government to change } \\
\text { the building } \\
\text { requirements for aged } \\
\text { care facilities }\end{array}$ \\
\hline
\end{tabular}

When analysing our respondents' controls we also noted that many were not only related to the physical building but to other activities that occurred within it. To understand this further we used a model produced by Markus et al (1972) to analysis our results. Despite being forty years old, Markus' model is still as relevant and as useful today to show how the building sub system relates to other sub systems in an organisation. According to Markus et al, a building facility and its stakeholders can be seen as an 'adaptive system' which comprises five key elements (sub-systems): the building system; the environmental system; the activity system; the objectives system and the resources system. The Building System comprises the external envelope; the structure; the division of internal spaces, services and contents. The Environmental System refers to the internal building environment created by the building system. The Activity System represents what happens within the facility and the Resources System represents the external environment from which the other sub systems draw to enable them to function effectively. This includes the supply of physical, financial and human resources. In simple terms, the building system creates the environmental system which people inhabit and use to perform activities in order to achieve defined organisational objectives.

Combining Markus et al's ideas with the concept of endogenous and exogenous controls, Table 2 shows an example of the typical types of activities that were classified into each category.

\begin{tabular}{|c|c|c|c|c|c|}
\hline & & \multicolumn{4}{|c|}{ Sub-systems } \\
\hline & & Building & Environment & Activity & Objectives \\
\hline 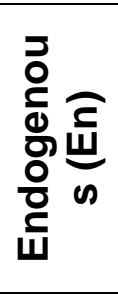 & $\mathbf{W}$ & $\begin{array}{l}\text { Program to } \\
\text { replace } \\
\text { defective steel } \\
\text { windows to } \\
\text { aluminium ones }\end{array}$ & $\begin{array}{l}\text { Set up a } \\
\text { pseudo } \\
\text { pharmacy/food } \\
\text { etc service for } \\
\text { visitors }\end{array}$ & $\begin{array}{l}\text { Improve internal } \\
\text { communication } \\
\text { s relating to } \\
\text { early warning - } \\
\text { give staff time } \\
\text { to move cars, }\end{array}$ & $\begin{array}{l}\text { Develop a } \\
\text { policy to call in } \\
\text { staff when early } \\
\text { warning } \\
\text { received }\end{array}$ \\
\hline
\end{tabular}




\begin{tabular}{|c|c|c|c|c|c|}
\hline & & & & etc & \\
\hline & $\mathbf{P}$ & $\begin{array}{l}\text { Avoid flat roof } \\
\text { when next } \\
\text { replacing it } \\
\text { (during an } \\
\text { extension } \\
\text { perhaps) }\end{array}$ & $\begin{array}{l}\text { Temporarily } \\
\text { move ED up to } \\
\text { day procedures } \\
\text { unit }\end{array}$ & $\begin{array}{l}\text { Develop } \\
\text { telehealth links } \\
\text { to tertiary } \\
\text { centres }\end{array}$ & $\begin{array}{l}\text { Provide policy } \\
\text { to support other } \\
\text { hospitals }\end{array}$ \\
\hline & 0 & $\begin{array}{l}\text { Build a new } \\
\text { hospital }\end{array}$ & $\begin{array}{l}\text { Lobby Council } \\
\text { to address } \\
\text { maintenance of } \\
\text { road as a top } \\
\text { priority }\end{array}$ & (none recorded) & (none recorded) \\
\hline $\bar{x}$ & $\mathbf{W}$ & $\begin{array}{l}\text { Look at other } \\
\text { accommodation } \\
\text { near hospital } \\
\text { site to house } \\
\text { additional } \\
\text { patients/visitors } \\
\text { - hotel is } \\
\text { community } \\
\text { owned so } \\
\text { negotiation is } \\
\text { easy }\end{array}$ & $\begin{array}{l}\text { Use alternative } \\
\text { sites such as } \\
\text { local school } \\
\text { ground to land } \\
\text { helicopter in } \\
\text { event of high } \\
\text { wind }\end{array}$ & $\begin{array}{l}\text { Set up } \\
\text { automated early } \\
\text { warning system }\end{array}$ & $\begin{array}{l}\text { Develop a } \\
\text { community } \\
\text { welfare/disaster } \\
\text { plan to consider } \\
\text { issues such as } \\
\text { accommodation } \\
\text {, food etc. }\end{array}$ \\
\hline 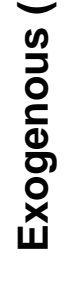 & $\mathbf{P}$ & $\begin{array}{l}\text { Talk to power } \\
\text { company about } \\
\text { using hospital } \\
\text { as a test bed for } \\
\text { solar generation }\end{array}$ & $\begin{array}{l}\text { Liaise with } \\
\text { other Council } \\
\text { agencies to use } \\
\text { their fleet during } \\
\text { an event }\end{array}$ & $\begin{array}{l}\text { Negotiate with } \\
\text { private } \\
\text { developer to } \\
\text { build car park }\end{array}$ & $\begin{array}{l}\text { Work together } \\
\text { with Council } \\
\text { and SES to } \\
\text { develop } \\
\text { mitigation } \\
\text { strategy }\end{array}$ \\
\hline & 0 & $\begin{array}{l}\text { Lobby RTA } \\
\text { (Road \& Traffic } \\
\text { Authority) to } \\
\text { upgrade road }\end{array}$ & $\begin{array}{l}\text { Lobby council } \\
\text { to fix their } \\
\text { services }\end{array}$ & $\begin{array}{l}\text { Help aged-care } \\
\text { facilities secure } \\
\text { funding to } \\
\text { develop risk } \\
\text { management } \\
\text { controls }\end{array}$ & $\begin{array}{l}\text { Lobby } \\
\text { government to } \\
\text { make risk } \\
\text { management } \\
\text { part of aged } \\
\text { care facility } \\
\text { accreditation } \\
\text { process }\end{array}$ \\
\hline
\end{tabular}

Table 2 Examples of adaptive controls in each coding category

Table 3 shows the results of categorising all 158 adaptive controls identified by our respondents using this coding framework. 


\begin{tabular}{|l|c|c|c|c|c|c|c|c|}
\hline & & & & $\mathbf{W}$ & $\mathbf{P}$ & $\mathbf{O}$ & All \\
\hline En & 30 & 22 & 28 & 29 & & & & 109 \\
\hline $\mathbf{W}$ & 20 & 18 & 25 & 25 & 88 & & & \\
\hline $\mathbf{P}$ & 5 & 3 & 3 & 4 & & 15 & & \\
\hline $\mathbf{O}$ & 5 & 1 & 0 & 0 & & & 6 & \\
\hline $\mathbf{E x}$ & 11 & 8 & 19 & 11 & & & & 49 \\
\hline $\mathbf{W}$ & 2 & 2 & 13 & 4 & 21 & & & \\
\hline $\mathbf{P}$ & 5 & 3 & 5 & 2 & & 15 & & \\
\hline $\mathbf{O}$ & 4 & 3 & 1 & 5 & & & 13 & \\
\hline $\begin{array}{l}\text { TOTA } \\
\text { L }\end{array}$ & $\mathbf{4 1}$ & $\mathbf{3 0}$ & $\mathbf{4 7}$ & $\mathbf{4 0}$ & $\mathbf{1 0 9}$ & $\mathbf{3 0}$ & $\mathbf{1 9}$ & $\mathbf{1 5 8}$ \\
\hline
\end{tabular}

Table 3 Adaptive controls by sphere of influence

Table 3 shows that adaptive controls in dealing with the risks of extreme weather events in hospitals are quite evenly spread across the building (41), environmental (30), activity (47) and objectives (40) systems. This indicates that any response to an extreme weather event must be a balanced one across these different sub systems. Given that stakeholders in the ROMS focus groups were evenly balanced across all functional groups in the hospital system, this would also seem to contradict the literature in facilities management which claims that the relationship between health service outcomes and hospital performance is neglected in the health sector and that infrastructure is an under-appreciated and under-utilised resource (McGregor and Then 1999, Valins and Salter 1996). If this were the case then one would have expected to have seen the controls focussed into the three other "non building" categories. Furthermore, Table 3 shows that most of the controls were endogenous (109) rather than exogenous (49). That is, they were generally independent of external stakeholders' cooperation. Nevertheless, it is also clear that wider exogenous governance structures and factors at state and federal levels have an important bearing on a hospital's ability to respond to an extreme weather event.

It is also interesting from Table 3 that most of the adaptive responses to extreme weather events are within the sphere of influence $(W=109)$ of the stakeholders in our focus groups and that the building system has the highest proportion of endogenous controls (30), followed by the objectives (29), activity (28) and environmental (22) systems. This suggests that the building itself is a source of adaptive capacity which can be changed without recourse to external (and therefore relatively uncontrollable) powers. However, when one looks at the relative $\mathrm{W}, \mathrm{P}$ and $\mathrm{O}$ totals for each sub system, then the building system has the greatest $\mathrm{O}$ score $(5+4=9)$ compared to the environmental system $(1+3=4)$, Activity system $(0+1=1)$ and Objectives system $(0+5=5)$. As a proportion of total controls $(9 / 44=20.45 \%)$ this represents the highest proportion of $O$ scores of any sub system (environment $4 / 22=$ 18.18\%; Activity $1 / 28=3.57 \%$; Objectives $5 / 29=17.24 \%$ ). This indicates that while the building system is an important source of adaptive strategies to cope with extreme weather events, the controls associated with the building system were, relatively speaking, outside the sphere of influence of our stakeholder group. Managers might therefore be tempted to look first at changing the activity and objectives system since these contained by far the largest proportion of controllable strategies - thereby enabling a faster response to an extreme weather event 
scenario. This may help explain why previous research has shown that hospital buildings are undervalued in healthcare management.

\section{Conclusion}

The aim of this paper was to explore the range of controls that hospital organisations can put in place to mitigate the risk of extreme weather events. Our findings indicate that hospital buildings and the facility managers that manage them are an important part of a much larger open system which must work in an integrated way if any response is to be effective. Given that one part of the system cannot be considered in isolation this raises important governance issues for facility managers which should be explored in future research. Our findings also show that it is important for hospital facility managers to work cooperatively with other external authorities such as public infrastructure, aged care, and government organisations in developing effective responses.

There are clearly a wide range of adaptive strategies which can be used to respond to an extreme weather event that span across hospital building, environment, activity and objectives systems. However, it is also clear that while some building system strategies are within the control of healthcare organisations (without recourse to external agencies) they are often among the least controllable strategies that can be enacted. The building sub system may be relatively uncontrollable compared to other sub systems in hospitals because once constructed, building elements are takes a relatively long time to change. Our research suggests that it may be related to the inflexibility of hospital designs and the dispersed internal governance structures that control these resources. Our research also supports Haigh and Amaratunga's (2010) view that more focus needs to be given to the built environment in the context of disaster prevention and management.

\section{Acknowledgements}

The authors wish to acknowledge the contribution of our partners in this research: Prof Andy Pitman, Co-director of the Climate Change Research Centre at UNSW; Prof Tony McMichael and Dr Keith Dear, National Centre for Epidemiology and Population Health at ANU; Mr Mark Meurisse of Palisade Asia-Pacific Pty Limited; and our industry partners NSW Department of Health, Government of South Australia Department of Health and New Zealand Ministry of Health.

\section{References}

ABCB (2011) Construction of Buildings in Flood Hazard Area (Information Handbook) 4th ed. Canberra: Australian Building Codes Board, Canberra, Australia.

Achour, N. \& Price, A.D.F. (2010) Resilience strategies of healthcare facilities: present and future. International Journal of Disaster Resilience in the Built Environment, 1(3), pp.264-276.

AlHA (2010) Australasian Health Facility Guidelines 1st ed. Australasian Health Infrastructure Alliance, Canberra, Australia. 
Becker, F and Carthey, J (2007) Evidence Based Healthcare Facility Design: Key Issues in a Collaborative Process. "Interdisciplinarity in Built Environment Procurement CIB WO92 Symposium", 23-26 September 2007, University of Newcastle, Australia.

BRANZ Ltd, (2007) An assessment of the need to adapt buildings to the unavoidable consequences of climate change, Department of the Environment and Water Resources, Australian Greenhouse Office, Canberra, Australia.

Carthey, J., Chandra, V. \& Loosemore, M. (2009) Adapting Australian health facilities to cope with climated related extreme weather events. Journal of Facilities Management, 1, 36-51.

DEWR (2007) An assessment of the need to adapt buildings for the unavoidable consequences of climate change. Department of the Environment and Water Resources. Canberra, ACT, Australian Greenhouse Office.

FEMA, (2007a) Design Guide for Improving Critical Facility Safety from Flooding and High Winds: Providing Protection to People and Buildings, Federal Emergency Management Agency. New York, USA

FEMA, (2007b) Design Guide for Improving Hospital Safety in Earthquakes, Floods, and High Winds: Providing Protection to People and Buildings, Federal Emergency Management Agency. New York, USA

FEMA, (2012) Engineering Principles and Practices of Retrofitting Floodprone Residential Structures Third Edition. Federal Emergency Management Agency. New York, USA

FEMA, (2010) Hazard Mitigation Field Book - Roadways, Federal Emergency Management Agency, New York, USA

Forrester, J W (1994) System Dynamics: systems thinking and soft OR, System Dynamics Review, Summer, 10 (2).

Georgoulis, S W (2008) Facilities management: a profession at risk, Unpublished Thesis, Arizona State University

Guest, G. and E. McLennan (2003). "Distinguishing the Trees from the Forest: Applying Cluster Analysis to Thematic Qualitative Data." Field Methods 15(2): 186201.

Haigh, R., \& Amaratunga, D. (2010). An integrative review of the built environment discipline's role in the development of society's resilience to disasters. Internal Journal of Disaster Resilience in the Built Environment, 1(1), 14.

Hampton, A. (2011) Designing User-Friendly Passive Buildings, Australian Institute of Architects, Sydney, Australia.

Helman, P. et al., (2010) Storm Tides, Coastal Erosion and Inundation, Gold Coast, Australia: National Climate Change Adaptation Research Facility, Sydney, Australia 
Hennessy, K., B. Fitzharris, et al. (2007). "Australia and New Zealand. Climate Change 2007: Impacts, Adaptation and Vulnerability. Contribution of Working Group II to the Fourth Assessment Report of the Intergovernmental Panel on Climate Change." 507-540.

Hiete, M , Merz, M and Schultman F (2011) Scenario-based impact analysis of power outages on healthcare facilities in Germany, Disaster Resilience in the Built environment, 2 (3) 222-245

ISDR, (2008) ISDR-Biblio 3: Health, Disasters and Risk, United Nations International Strategy for Disaster Reduction Secretariat.

Kiern, A.S. et al., (2010) Learning from Experience: Historical Case Studies and Climate Change Adaptation, Gold Coast, Australia: National Climate Change Adaptation Research Facility, Sydney, Australia.

Klein K R, Rosnthal, M S and Klausner H A (2005) Blackout 2003: preparedness and lessons learned from the perspectives of foure hospitals, prehospital and disaster Medicine, sept-Oct 20 (5), 321-332

Linnenluecke, M. and A. Griffiths (2010). "Beyond adaptation: Resilience for business in light of climate change and weather extremes." Business Society OnlineFirst 1: 1-35.

Luber, G. \& McGeehin, M., (2008) Climate Change and Extreme Heat Events. American Journal of Preventive Medicine, 35(5).

Markus, T A, Whyman, P, Morgan, J, Whitton, D, Maver, T, Canter, D and Fleming, J. (1972) "Building Performance". London: Applied Science Publishers Ltd.

Mason, M. \& Haynes, K., (2010) Adaptation Lessons from Cyclone Tracy, Gold Coast, Australia: National Climate Change Adaptation Research Facility, Sydney, Australia

McGregor, W and Then, D S (1999) Facilities Management and the business of space, Butterworth-Heinemann, New York.

McGeorge, D, Chow, V W, Carthey, J, \& Loosemore, M. (2011) Modelling the impact of extreme weather events on healthcare infrastructure using rich picture diagrams. Paper presented at the Association of Researchers for Construction Management (ARCOM) Conference, Bristol, United Kingdom.

McMichael, A. J. \& Woodruff, R. (2007) Climate change and infectious disease. In: Walker, K. \& Pizer, H. (eds.) Social Ecology of Infectious Disease. New York: Academic Press.

Ministry for the Environment (2009). "How might climate change affect my region? Climate change in Northland." Retrieved 1 December, 2009, from http://www.mfe.govt.nz/issues/climate/about/climate-change-affectregions/northland.html.

Morgan, D. L. (1997), Focus groups as qualitative research, Thousand Oaks, California, Sage Publications. 
PAHO (2008). Hospital safety index: Guide for evaluators. Series hospitals safe from disasters, no.1. Washington DC, Pan American Health Organization.

Patching, D (1990) "Practical Soft Systems Analysis". London: Pitman Publishing. PCl (2011) Barriers to effective climate change adaptation, Productivity commission issues paper oct 2011, Prod commission, commonwealth gov of Australia

Pettigrew, A and McNulty, T (1995) Power and Influence in and Around the Boardroom, Human Relations August 1995 vol. 48 no. 8, 845-873

Pope, C., S. Ziebland, et al. (2000). "Qualitative research in health care: Analysing qualitative data." British Medical Journal 320: 114-116.

PWC (2011) Protecting human health and safety during severe and extreme heat events: a national framework, Commonwealth Government, Canberra November 2011, Price Water house Coopers

Radovic V, Vitale K and Tchounwou P B (2011) Health facilities safety in natural disasters: experiences and challenges from South East Europe, International journal of environmental research and public health, 8 (1), 67-83

ROMS (2011) "Risk and opportunity management system". Retrieved from http://www.risk-opportunity.com.

Shaw, R., Matsuoka, Y. \& Tsunozaki, E., (2010) A guide for implementing the Hyogo Framework for Action by local stakeholders, United Nations International Strategy for Disaster Reduction Secretariat.

Stern, N. (2009). The costs of delaying action. Climate change: Global Risks, Challenges \& Decisions Copenhagen 2009, University of Copenhagen.

Valins, M. and Salter, D. (1996) Futurecare : new directions in planning health and care environments, Blackwell Science 1996, Oxford.

Van Ree, C.C.D.F. et al., (2011) FloodProBE: technologies for improved safety of the built environment in relation to flood events. Environmental Science \& Policy, 14(7), pp.874-883.

Verdon-Kidd, D.C. et al., (2010) East Coast Lows and the Newcastle-Central Coast "Pasha Bulker" Storm, Gold Coast, Australia: National Climate Change Adaptation Research Facility, Sydney, Australia.

WHO (2004) Heatwaves: risks and responses. Geneva: World Health Organisation. WHO, (2009) Natural ventilation for infection control in health-care settings, World Health Organization.

WHO, (2010) Safe Hospitals in Emergencies and Disasters, World Health Organization. 
